\title{
PRNP wt Allele
}

National Cancer Institute

\section{Source}

National Cancer Institute. PRNP wt Allele. NCI Thesaurus. Code C71443.

Human PRNP wild-type allele is located in the vicinity of 20p13 and is approximately $15 \mathrm{~kb}$ in length. This allele, which encodes major prion protein, plays a role in both the extracellular surface and the development of prion diseases. Mutations in the gene are associated with inherited transmissible spongiform encephalopathies. 